\title{
LGBT Students' Short Range Narratives and Gender Performance in the EFL Classroom*
}

\author{
Narrativas de estudiantes LGBT y la representación de \\ género en la clase de Inglés como lengua extranjera
}

\author{
Francisco Rondón Cárdenas \\ Teacher and Academic Supervisor \\ Centro Colombo Americano \\ Bogotá - Colombia \\ E-mail:pachonojavier@hotmail.com
}

Received: 24-Aug-11 / Accepted: 10 - May - 12

\section{Abstract}

By means of the analysis of six short range narratives, utilizing as a methodology (Feminist Post-Structuralist Discourse Analysis) FPDA, this paper unveils some significant moments which evidence the way LGBT EFL students draw on different discourses to adapt, negotiate, resist, emancipate, and reproduce heteronormativity. EFL students Methodological Framework

Constantly shift positions and perform their gender assuming simultaneously powerful and powerless stances in the EFL classroom. The study categorizes the emancipatory discourse as a way to resist, the discourse of vulnerability as a way to reproduce and cope with marginalization, and the homophobic discourse as a way to position LGBT individuals as abnormal. Finally, the article will reflect on the moments LGBT student mitigate their oral skills and constrain their participation in class, due to the fact that they are frequently evaluating their comments to avoid accidental disclosure of their sexual identity.

Key words: LGBT individuals, Post-structuralism, discourse, gender, FPDA (Feminist post-structuralist discourse analysis).

\section{Resumen}

Por medio del análisis de seis narrativas cortas este documento revela algunos momentos significativos que dan evidencia del modo como los estudiantes LGBT de Inglés como lengua extranjera asumen posiciones para adaptarse, negociar, resistir, emanciparse y reproducir la heteronormatividad. Esto usando la Metodología FPDA (análisis posestructuralista feminista del discurso). Los estudiantes LGBT se posicionan y demuestran su género asumiendo posiciones de poder y marginalización simultáneamente en el salón de clases. Este estudio categoriza diferentes discursos, como el discurso de emancipación; este como una manera de resistir. También, el discurso de vulnerabilidad como una forma de reproducir estructuras y así lidiar con la marginalización. Finalmente, el discurso homofóbico como la forma de posicionar a los individuos LGBT en desventaja como personas subnormales. Para terminar, el artículo refleja los momentos en que los estudiantes LGBT mitigan sus habilidades orales y constriñen su participación para evitar muestras accidentales de su identidad sexual.

Palabras Clave: Miembros de la comunidad LGBT, Postestructuralismo, discurso, análisis feminista y postestructuralista del discurso, género)

* This research study was a requirement to obtain the M.A. degree in Applied Linguistics to TEFL at Universidad Distrital Francisco José de Caldas. The participants of the study were contacted through referral chains among the same participants. They belong to different language centers and universities. 


\section{Introduction}

This study aims to explore the way EFL LGBT (Lesbian, gay, bisexual, and transgendered) students perform gender in the classroom by means of a qualitative methodology called FPDA (Feminist Post-structuralist Discourse Analysis). The study unfolds in the theoretical framework of post-structuralism and its understanding of gender and sexual identities. In order to unveil the moments when LGBT students perform gender as significant events, the study utilizes short range narratives as a unit of analysis. These short range narratives are analyzed at a connotative and denotative level so as to explore the moments in which gender in relation to power emerges.

In regards to these practices, the study compiles six short range narratives which illustrate the several competing and unstable discourses LGBT individuals draw on in order to challenge, resist, negotiate or adapt to the heteronormative classroom discourse. In order to ascertain these moments, I describe the way the participants' roles take on powerful or powerless positions. This analysis is possible by means of the use of FPDA; such a theory provides the foundation to ask questions about interaction that move beyond a strictly linguistic focus (Fairclough, 1989). Moreover, this study may demonstrate how participation and interaction mediated through gender constructions support and constrain English language learners' classroom participation.

I used Salganik's (2004) snowball sampling technique which is a method that involves the selection of participants utilizing "insiders", in this case LGBT students and referral chains among other subjects who possess these common traits (belonging to a non heterosexual identity and being an EFL student). By means of this technique I could identify 21 participants; namely 2 lesbians, 2 bisexuals, 17 gays, and no transgendered. They answered a survey via e-mail and then, only six of them voluntarily provided short narratives in a subsequent semistructured interview. The participants range between 18 and 32 years old and have pursued or are pursuing different undergraduate majors at various universities in Bogotá.

\section{Language and the Existential Competence}

The Common European Framework (CEF) is the framework of reference adopted by "The National Program of Bilingualism" ${ }^{1}$ and it states that, besides communicative competence in foreign languages, there is a set of general competences which must also be addressed to elaborate curricula. Indeed, it is necessary to consider language learners and users in regard to their knowledge, skills, existential competence and ability to learn. This study is tightly related to gender which appertains to the domain of the existential competence. Therefore, I will focus on this competence which may be considered as the sum of the individual characteristics, personality traits, and attitudes; for instance, self-image, identities, one's view of others and willingness to engage with other people in social interaction. As it is stated in the CEF (2001), communication is affected not only by the learner's knowledge, understanding, and skills, but also by selfhood factors connected with their individual personalities, characterized by the attitudes, motivations, values, beliefs, cognitive styles, and personality types which contribute to their personal identity. The recognition of the existential competence in EFL learning justifies my two main questions, which are: What do LGBT students' short range narratives unveil in regards to gender in the EFL classroom? and How does LGBT students' gender performance influence EFL learning?

1 A bilingual plan intended to be implemented from 2004 until 2019 all throughout Colombia. (Supported by the Law 115; 1994) 


\section{Post-Structuralism and Queer Theory}

Post-structuralism is a philosophical stream which groups a set of principles which do not have a single theoretical framework, but an association with a wide collection of principles that makes the theory identifiable, and self reflexive. Post-structuralism complies with several premises. One of those is "to be skeptical towards universal theories" (Baxter, 2003, p.23) Post-structuralism argues that individuals are not uniquely positioned, but are produced as a "nexus of subjectivities" (Harré, 1990) in relations of power that are constantly shifting. Thus, it may be that the same individuals are simultaneously powerful and powerless within same discursive contexts. That is one of the reasons why poststructuralism does not agree with universal causes as to emancipate all the individuals who are supposed to correspond to the same traits of oppression, in the case of this study, LGBT members.

LGBT students within the same discursive context may experience positions of relative powerfulness and powerlessness either concurrently or in rapid succession (Walkerdine,1990). LGBT individuals, on the one hand, may be high achievers in terms of fulfilling tasks, accuracy, linguistic features, written production, etc. (powerful). On the other hand, they may be silent, less participative in regards to existential features of the language e.g. talk about own feelings, likes, social intercourse experiences, etc (powerless).

Baxter (2003) also proposes "the contestation of meaning"( $p, 26)$; it recognizes that meaning is social and is continuously reconstructed, negotiated, and contested through language and discourse. The contestation of meaning comes along with another underlying assumption which is "the discursive construction of subjectivity". It means that, individuals are not socially produced, either determined nor free but both simultaneously (Baxter, 2003). This principle is achieved as people being intentional subject (actors) in the world and in their own selves as well as subjected to forces beyond their conscious control.

Immersed in post-structuralism Queer Theory emerges. "This theory was born in the ideas of Post-structuralism, and deals with deconstruction and some psychoanalytic theories, that deny the validity of structuralism's method of binary opposition" (Nicholson, 2001, p. 118). The originators and inspirers of Queer Theory are Michel Foucault and Jacques Derrida, and both of them agreed to define sexual identity in the field of gender as acts not facts. This construct in the Queer Theory occurs within the social constructionist view that identities are continuously performed; in other words, gender "has constantly to be reaffirmed and publicly displayed by repeatedly performing particular acts in accordance with cultural norms (...) which define masculinity and femininity" (Cameron, 1997b. p. 49).

Principally, Post-structuralism and Queer Theory permit a non-biological understanding of gender. Accordingly, within Queer Theory sex and gender are interrelated but not dependent on one another (Butler, 2001). Historically, it has been claimed that gender overlaps, is determined, and even exists immersed in sex (male and female) and both, gender and sex, determine the object to be adequately desired. The queer understanding of gender is how femininities and masculinities are performed (acts, not facts) by an individual without any preexisting category that determines what is politically correct or normal to be performed (Spurlin, 2000). Likewise, the biological distinction between male and female does not determine gender (what an individual performs in different scenarios as historically has been constructed as "feminine and masculine"); thus, what is sexually adequate to be desired neither belongs to any preexisting category nor is determined by gender or sex (Butler, 2001). 
Essentially, most of us, most of the time, are not aware of performing anything in such a highly self-conscious way. What we are doing, however, is "materializing gender/sexual identity/desire by repeating, consciously or not, the acts that conventionally signify femininity or masculinity" (Cameron E Kulick, 2003, p.150). These identity categories (heterosexual / homosexual, man/ woman) are, like other "clusters of ideas, images and practices" or discourses (Hall, 1997, p. $6)$, structured and circulated through linguistic human interaction (Foucault, 1972). Likewise, they are materialized through an everyday "performativity" of straightness, queerness, maleness, and femaleness. Consequently, they are indeed acts not truths or facts.

\section{Heteronormativity}

As previously stated, the queer understanding of gender is embedded in social structures and everyday interaction. Therefore, it is paramount to bring up heteronormativity, or "The belief that humanity is the same that heterosexuality" (Foucault, 1990, p. 44) LGBT individuals are regarded to be abnormal and deviant in relation to their divergent personality traits, abilities, and motives. They are comprehended and valued at a disadvantage according to what is commonly believed to be typically "gay" or homosexual. This understanding is comprehended through the Lens of what is normatively predetermined heterosexual. This understanding results in exclusion and disrespect in any social context due to the fact that individuals are overlooked, resulting in poor comprehension of "others".

\section{Short Range Narratives to Unveil Gender Performance}

The unit of analysis this study explores is short range narratives; this is a prototype of narrative which is according to Linde (1993), "a retell that gives an account of a certain landmark or key event or experience that is considered to be pivotal in the formation of the interviewee's sense of the self" (p. 12). This type of narratives differs from the narratives that generate data by an autobiographical interview which is usually regarded and analyzed as a monological narrative drawn from autobiographical memory (Bruner, 2004)

When an individual recalls a memory it may probably differ from the actual facts. As Ricoeur (1983) asserts "we try to gain by means of imaginative variation of our ego a narrative understanding of ourselves" (p. 437). In this regard, as this study is framed in poststructuralism, it is necessary to incorporate the tension between interaction and subject positioning, both reflectively (the way one positions oneself) and interactively (the way others position us) (Sunderland, 2002).

This work comprises the notion of narrative identity within the context of the philosophical work of both Heidegger (1927) and Ricoeur (1983, 1987, 1990). Hence, the analysis of the short range narratives embrace these three fundamental transformations of reality, in terms of:

- Temporality (Heidegger, 1927) "time",

- Mattering (Heidegger, 1927) "concern"

- Configuration out of a succession

(Ricoeur, 1983)

In regards to temporality, Heidegger (1945) challenges the common human understanding of time that comes in the order of past, present and future. Heidegger (1982) conceives of time in terms of retention, attention, and protention. Retention is the active recollection and selection of memories which are defectively linked to the future and present. Attention is the way we construct the event and the emotions it carries at the moment of retelling, and as the way we give meaning to and modify events emphasizing on some aspects and deleting some others. The human being is not confined in the 
past when he retells in present, as a matter of fact, any individual always projects towards the future (protention). This is what Heidegger calls "the moment of vision", literally "glance of the eye". When retelling, individuals may find the opportune moment to modify their past and present, at least, as part of an imaginary, hypothetical situation.

Secondly, Heidegger postulates his concern of why it is important for the individual to tell a narrative; a narrative event recognizes the meaningfulness of an individual experience by noting how it functions as part of a whole; then, by means of a plot, a list of events can be transformed into a schematic whole in such a way that it recognizes the contribution that certain events in our lives make to the development of our selves (Bruner, 2004).

Finally, "the configuration out of a succession" (emplotment), (Ricoeur, 1983), this comes along with the identification of significant moments, which, according to Wooffitt (2005, p. 115), are events identified by the next formula "I was doing $\mathrm{X}$ when Y". Generally speaking, all the participants' short range narratives would be one more in a list of customary moments in the classroom if the episode was not attached to a schematic whole that projects something significant in their construction of the self as being queer; this is a well known configuration out of succession. It draws on the Ricoeurian philosophical approach of the domain of action. He acknowledges the human competence to distinguish relations of cause - effect and the different roles of action to join narrative events in a monolitical unit. He claims that actions imply goals, motives, and outcomes; these actions also take place in certain circumstances and in different ways of interaction (Ricoeur, 1976).

\section{LGBT Students in Gender Studies}

There are some pivotal pieces of research that in the last few years have fruitfully contributed the arena of queer studies in relation to English as second/foreign language, for instance; qualitative research carried out on textbooks in EFL for secondary school by Guijarro (2006) in Spain; in this study, the author analyzes some books in terms of gender and sexual orientation in axiological parameters such as values and local moral standards. As a result, he exposes the implications of the hidden curriculum as a way to hinder sexual orientation through books. There are also action research projects which intend to include sexual identities in literacy practices as a way to unveil gender issues within the heterosexual stopovers which limit the inclusion of queer issues. The authors (Brooks, 1999; Summerhawk, 2001; Nelson, 2004; Guijarro, 2006) emphasize the importance of using Queer Theory for classroom inquiry since queer issues have not been broadly explored. These pieces of research are usually conducted in class at a community college and high schools by the implementation of grammar content, speaking/ listening lessons, and academic writing classes. These pieces of research predominantly agree with the fact that LGBT identities are silenced in books and curricula. Therefore, they conclude that one of the challenges of working with the topic of lesbian or gay identities, particularly the first time it is raised, is that teachers may be unsure or ignorant about 1) whether students are interested in or familiar with this topic; 2) or if such a topic will be disruptive, irrelevant or inappropriate to the academic community. According to the above mentioned authors, the results and post analysis may be of interest to learners, teachers, teacher educators, publishers, etc who really need to be able to refer to and discuss not just heterosexual, but also lesbian, gay, bisexual and transgendered identities.

In general, studies in queer issues tend to include material and queer topics in the curricula, as was done by Nelson (2004). She 
explores in her book in 9 chapters what kind of practices in EFL classrooms are appropriate to give rise to productively tackle socio-sexual aspects of language, identity, culture and communication. The project was carried out with one hundred teachers and trainees in three different classrooms in the US. The purpose of the study was to provide EFL teachers with structured guidance to approach queer themes, taking into account the complexities and challenges that this may imply. In spite of these studies, there is not a strong account of Colombian descriptive studies of LGBT individuals and the way they tackle sexual identity in the EFL classroom. For this reason, I find my study may be particularly contributive since it describes a scenario that has not been deeply explored.

\section{I am Talking About a Girl}

\section{The Discourse of Emancipation}

FPDA offers an adequate way to not only release the words of silent groups ( i.e. LGBT community), but also to advertise and make issues public in an academic world saturated by stereotypes, prejudices and fears towards this population. This study does not intend to exclusively ascertain versions of LGBT individuals as universal victims but as individuals who should be reconstituted as potentially powerful in terms of their multiple positioning within different discourses. FPDA appreciates unevenness and ambiguities in order to understand the different modes of domination and the multiple agency LGBT students, in this case, may assume to engage in dominant discourses. More importantly, there is a need to mention that no individual is in constant or perpetual state of victimization.

A narrative event that demonstrates this is Adriana's. She is a 24 year old out of the closet ${ }^{2}$ lesbian, an EFL student who assumes an

2 "Out of the closet" Colloquial term to address individuals who display their gender and sexual preferences in different scenarios active role in the construction of her identity. She resists the heteronormative discourse of her teacher and, as a means of emancipation, she comes out of the closet with her in the classroom. Adriana is participating in an EFL activity where she has to share orally with some other classmates on some topics of conversation the teacher has written on the board, in this case "the happiest moment students have ever lived". This is a short sample of what she recalls:
20.yo comencé a decir la historia
21.y yo decía she y que ella venía
22.y que ella estaba en el bar y que ella me estaba viendo
23.y entonces si ya; la profe siempre me corregía
24.y me decía He
25. y yo eso, eso (3) jeh! y otra vez (risas)
26.y no; recuerdo que como a la tercera vez
27. yo le dije profe yo estoy hablando de una niña
28. yo tengo novia y ella se me quedó mirando así muy incómoda
29- todo el mundo así (4) nadie se rió (3)
(Adriana, personal communication 2010) ${ }^{3}$

Adriana is retelling the story of "the happiest moment she has ever lived". The activity is one referring group sharing of personal anecdotes framed in the grammar content of superlatives and present perfect. The participants, in regard to active agents, are the student (Adriana) and a female teacher. This teacher presumably draws on a heteronormative discourse to understand Adriana's story. It is certainly obvious for the teacher that Adriana is not being coherent in terms of grammar when she apparently produces sentences which are "wrong" in terms of cohesion between subject (Adriana) and object (the person she was dating): "y que ella estaba en el bar y que ella me estaba viendo"

without fear, prejudice, or preconception. 3 Names of participants are pseudonyms 
According to the teacher's point of view, if you are a female and you are telling a romantic story, the predicate must correspond to a male character. That is why she corrects Adriana three times. At the beginning, Adriana understands primarily her teacher's discourse, and intends to adapt herself to this heteronormative logic. Adriana agrees to correct herself by adding a male object (him) to her retelling. However, at some point she resists her momentary role as a silent person in regards to her sexual identity, therefore, she comes out as a lesbian. She may want to claim that she is speaking correctly. She shifts power relations and negotiates through the medium of the competitive discourse at play and draws on a different discourse, the one of emancipation. Adriana is an EFL student, a female, and a lesbian among other ascriptions. And her counterpart is an EFL teacher, a female who assumes a heteronormative perspective. In regard to the teacher-student relationship, Adriana seems to be powerless when her teacher corrects her. This teacher adopts a powerful position as an accurate knower of English. Additionally, she interactively positions Adriana in a powerless role since for her, she is constantly making a mistake which is interfering communication. Nevertheless, Adriana, takes up a different role to be positioned for what she says; she reflectively positions herself as an EFL lesbian student who has awareness of the role of personal pronouns and object pronouns when constructing an statement.

At some point, EFL teachers draw on this taken for granted-heteronormative discourse to lesson plan and guide students in the way it is accurate and "normal" in terms of grammar. This constant reaffirmation of "normal" talk, for instance, a male talking about females and a female talking about males, at least when romantic themes are brought into the lesson, implies a constant reaffirmation of what is "right" and "wrong" when expressing oneself. Needless to say, Adriana emancipates herself from this normalness.

\section{The Real World Mode and the EFL Mode The Discourse of Vulnerability}

This discourse takes individuals to draw on marginalized discourses, due to the fact that some LGBT students consciously or unwarily foresee threats if they emancipate from the heterosexual main stream. They reproduce and draw on a discourse of vulnerability in order not to be harmed, spotted, victimized, or rejected. Since they assume the role of minority, they tend to avoid unforeseen gender disclosure. In order to better explain this, I account for three students' short range narratives, which evince another way LGBT individuals reflectively position themselves. To start with, this is the way Edward reflects upon the fact of being asked questions that may accidentally expose him to public-gendered comments of any sort.

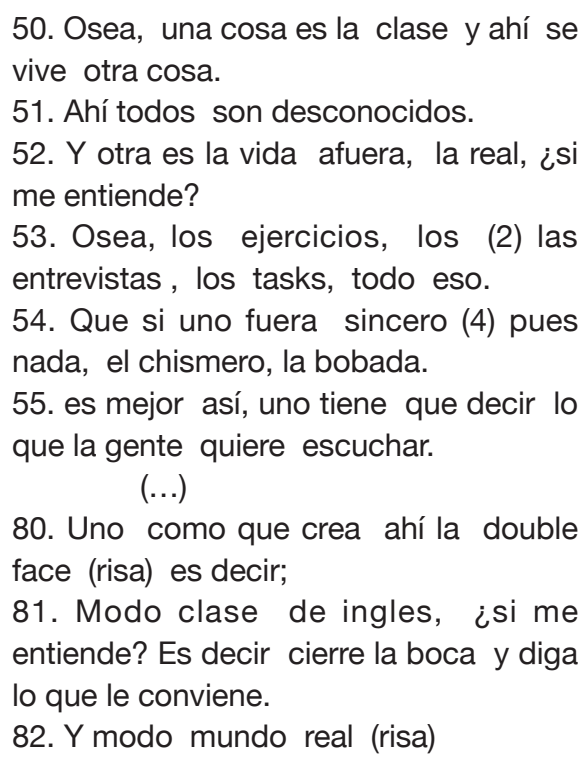

(Edward, personal communication, June 2009)

Edward talks about the exercises, the tasks, the interviews as regular activities that are carried out in class, and he assesses them as 
part of a different world, not a real world; in his own words (Modo clase de inglés... y modo mundo real) Edward's understanding of language is revealing in that he does not consider EFL as a way to personal expression; he actually does not perceive an existential issue in the language learning process since he is detaching his sexual identity from his self in the EFL setting. He does not understand language to convey meaning, not even to do activities in a meaningful way, but just as an instrument to be used to develop exercises in the classroom; he expresses a pure instrumental vision of EFL. More importantly, he brings up a computer language metaphor by using the word "mode": "Real life mode and EFL classroom mode". He invokes this metaphor to explain the way he behaves in these two settings; I understand this as "a discourse of vulnerability" (Cox $\&$ Gallois, 2006) as Edward himself expresses:

58. Que si uno fuera sincero (4) pues nada, el chismero, la bobada.

Edward, in his own words, provided me with a metaphor that clearly gathers the reflective positioning some students take up when drawing on a discourse of vulnerability. To better exemplify this metaphor, I will account for the two other short range narrative events.

In the first case, John participates in an EFL activity which deals with a listening and speaking exercise based on some famous soundtracks. The students have to guess the name of the movie and tell the plot to the group once they have listened to the soundtrack. One of the movies was Philadelphia, a recognized gay thematic movie which plot involves an AIDS case. John reveals in the interview that this is one of his favorite movies.

50. puso la (3) de una de mis películas favoritas

(John, personal communication, 2010)
What is singular is the way he reacts when he says the name of the movie out loud. This is a part of his short range narrative.

56. la película era Philadelfia

56. y yo sabía que esa era la banda sonora de esa película

57. pero como no era solamente decir el nombre de la película

58. de la banda sonora

59. sino explicar de qué se trataba la película

60. me llegaron a pedir la explicación de la película (2)de la (3)

61. de qué se trataba

62. y en ese momento no;

63. no; fui capaz de reconocer que esa era una película de temática gay

64. Porque:::: De pronto $\mathrm{mmmm}$ verse una película gay

65. no siempre le va a llevar a la gente a 66. que es una película que te puede dejar algo 67. siempre van a pensar que es una película porno

In the next sample, another student, Jorge, has to develop a "project" (his actual word). Firstly, he has to write a paper about a sportsman; however, due to his classmates complaints about the constraints of the topic, the teacher decides to be more lenient and allows students to write about artists and actors. Jorge takes advantage of this opportunity and decides to write something about Miguel Bosé, a recognized pop singer, who has openly admitted to being a bisexual. Up to this point, there is no dilemma to Jorge, until he is asked to participate in a debate with three more classmates. This is what Jorge narrates:

17. el profe se le ocurrió

18. que teníamos que hacer un debate

19. sobre lo que habíamos escrito y

20- junto con otros cuatro compañeros que teníamos ahí,

21. un debate, pues nada yo no quería hablar, (2)

Rondón F., (2012) Colomb. Appl. Linguist. J. ISSN 0123-4641 • Bogotá, Colombia. Pages 77-91 
22. pues obviamente de este man, de Miguel Bosé,

23. pues que voy a debatir algo que es de deportistas y

24. toda esa vaina con, (2) con un cantante ahí

25. que ya casi todo mundo sabe

26. que ahí como pues como es más o menos la personalidad de ese man (risa) (...)

38. entonces nada fui y le dije al profe que si podía,

39. igual ya había hecho el proyecto entonces que si podía averiguar sobre un deportista para debatirlo,

40. para no tener que hablar de Miguel Bosé,

41. y pues el man me dijo que si que lo cambiara pero pues por eso le digo, 42. pues que que me sentía como incomodo al hablar de $\mathrm{mmmmm}$

Both events occurred in an EFL setting and evidence the way selves are continuously reconstructed through interaction. Jorge and John draw on different discourses which comprise, as well, a way to understand, see, and talk about the world, and to become part of being within it (Castañeda-Peña, 2008). They draw on a discourse of vulnerabilty to power negotiation. John could have explained the plot of the movie and get the point the teacher was giving and Jorge could have participated in the debate talking about Miguel Bosé; nevertheless, it did not occur. This was due to the fact that these two gay students reproduced an internalized, stereotyped, and normalized construct of gay movies as being pornographic, and certain music tastes as not masculine. They reproduced what they think people, in general, think about gay thematic movies and certain tastes in music. Normalization turns into stereotyping when a set of predispositions that result from lived experiences turn into non-reflecting habitus. John, for instance, assumes his classmates may have believed that Philadelphia was a "pornographic gay movie" and Jorge presupposes that his classmates may probably have teased him afterwards due to this musical taste disclosure.

Moreover, Jorge is willing to write about Miguel Bosé if the teacher is the only one who reads his paper; he may consider his teacher respectful, mature and a non-agent of gossip, or he may think the teacher will only check the "grammar features" of his paper as he claims in the sample below.

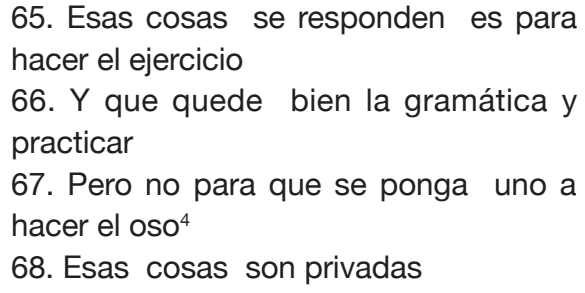

However; he is concerned about the implications of debating about Miguel Bosé with some other classmates; therefore, he does not care about wasting all his previous work when he changes the topic of the project from a singer to an athlete. He responds to the heteronormative power of the classroom in the same way John and Edward do. The three of them evoke a discourse of vulnerability when they anticipate the plausible consequences of public exposure of stereotypical gay tastes (e.g., pop music, gay thematic movies)

Regarding these three experiences, I posit that LGBT students are marginalized "others" who require a cognitive flexibility to comply with heteronormativity. This implies awareness of alternatives to cope with the common activities that represent no challenge at all for heterosexual students, as well as willingness to be flexible regardless of wasting

4 Colombian Spanish expression; being on the spot, a source of jokes 
time by developing a new project as in Jorge's case, or failing to obtain points in the class as in John's case.

Presenting another shape of the discourse of vulnerability, I evoke Baxter's (2003) words when she affirms that gender differentiation is, to a large extent, historically constructed and geographically widespread; she affirms that discourses are not some kind of fixed, reified, monolithic entity. They are, undoubtedly, always open to contestation, reconfiguration and redefinition. Discourses of gender differentiation produce widely contrasting subject positions and different interpretations of inequality. Edward, the participant who brings up the "class mode real world" metaphor is a pre-service EFL teacher, and he evaluates his future career in contrast to his (apparently) EFL gay teacher in this way.

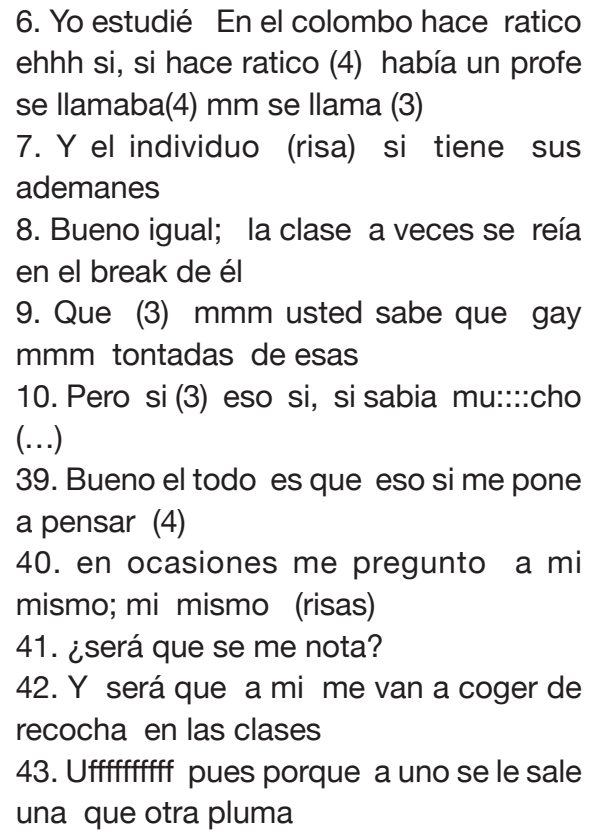

(Edward; personal communication 2009)

In turns 8, 9 and 10, Edward assumes a powerful position in regards to his "effeminate" teacher, somebody who knows a lot in contrast to the way he communicates with body language; then, in turns 39 to 44, he wonders about future difficulties with being a gay male EFL teacher. He wonders if he is effeminate as well. When retelling, individuals may find the opportune moment to modify their past and present, at least as part of an imaginary, hypothetical situation (protention). Therefore, Edward found an appropriate moment to reflect on his future as a gay teacher being probably effeminate. Clearly, discourses of gender differentiation not only vary from one cultural setting to another, but also they do not act alone. Gender discourses are vying with equally powerful, competing discourses. These are linked with specific cultural practices such as religion, political affiliation, or, in the case of these participants, status of masculinity and femininity when observing body language or likes. These narratives reveal how such discourses simultaneously produce tensions between, and connections with, competing discourses. Edward shifts from making fun of his gay teacher to wondering if he will be like him when he becomes a teacher. As is evidenced, at times LGBT members are blind to their own dominating and oppressive tendencies and discourse. In this manner, Jorge and Edward themselves are implicated in many forms of oppression of others who belong to their same sexual orientation. Gender is socially co-constructed; that is, it evolves partially from a process of affiliation to particular beliefs, behaviors and social groups, and partially from the attributions or ascriptions of others (Chouliaraki, 1989).

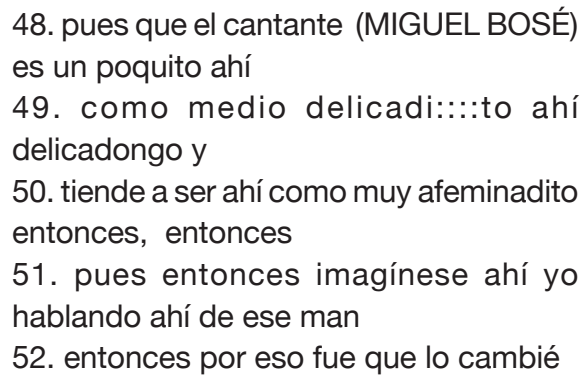

(Jorge, personal communication 2010) 
Jorge and Edward do not associate with effeminate gays; consequently, they ascribe them with negative attributions so as to position "the effeminate ones" in a lower status among gay males. In contrast, they disapprove of the way "society" rejects them for being gay. This internalized, ambiguous medley of ideas may encounter support in the historical construction of man (sex) and masculinity (gender) in the realm of heteronormativity.

\section{The Overt Homophobic Discourse}

Overt homophobia is the most explicit way to marginalize, underpin, victimize, and discriminate LGBT members since it is supported on a direct and explicit discourse that usually ends up in violent and pejorative talk and insulting acts. Andrés, a student of systems engineering, faced a peculiar situation with one of his English teachers; he labels his teacher's discourse as being homophobic due to the fact that this teacher is a "closet gay". This is Andrés' 'retelling:

25. pues si resulta que el profesor se la pasaba ahí

26. si pues osea, se la pasaba haciendo comentarios

27. poco agradables con el tema

28. y pues digamos que a ese señor no le gustaba escribir casi en el tablero

29. que disque no le gustaba darle la espalda a la gente

30. pues porque pues a ver que no sabía con que gente

31. se estaba metiendo

32. que nunca sabia uno con quien estaba atrás y quien lo perjudicaba

INTERVIEWER: ¿pero lo hacia en ese sentido como un comentario (4) como un chiste gay?

33. aja aja si que quien sabe que le hacían por detrás y así esas bobadas

(Andrés, personal communication 2010)

It is remarkable that these accounts occurred at different moments during a semester (about four months) and the student claims not to remember all the unpleasant comments this teacher used to make. However, he does remember three that could be briefly recalled in this way:

1. The teacher wants to explain the word "ojeras" and he uses as a resort, a famous politician who is currently the president of the nation, adding transvestite as a pejorative word to qualify him. The teacher could have just translated the word, however he added a joke about this politician.

2. He often affirms not liking writing on the board because he does not trust anybody on his back, adding a double meaning to this comment (e.g., heterosexual stereotype of gays being solely receptive in anal sexual intercourse ).

3. He is asked how to say "the bread with a hole in the middle", in Spanish, roscón, (a pejorative word to refer to homosexuals in Spanish) and he translates it as "gay bread".

That careless use of homophobic pejorative discourse will most certainly compromise the psychological health of Andrés by insidiously constructing his sexual identity as something wrong, to be ashamed of, and to make fun of. Furthermore, if one takes into account the position of power this teacher has, one can evaluate some other effects on the rest of the students, as Brockmeier (2001) argues "the use of such language creates an atmosphere of uncritical acceptance of intolerance toward homosexuality, while reinforcing stereotypical attitudes towards gays" (p. 321). To some extent, this teacher replicates the negative understanding of LGBT members as individuals who do not deserve respect.

Nonetheless, Andrés does not draw on a discourse of vulnerability, so he resists the 
position he is subjected to by his teacher as a resource of jokes and pejorative language. It is quite revealing the way Andrés reacts due to the fact that he shifts from the role of victim to simultaneously gain a powerful position when he positions himself as a gay in advantage to his teacher, who, in Andrés' words, is a gay, too, but a closet gay.

90. para mi que el tipo es gay (risas)

91. y por eso se la pasaba ofendiendo

92. para quitar cualquier duda (3) eh así son los closeteros INTERVIEWER: ¿closeteros?

93. Los del closet, lo que nunca salen ni con ellos mismos (risas)

(Andres personal communication 2010)

Andres presupposes and positions his teacher as a closet gay. Furthermore, probably in an unconscious way, he intends to challenge his teacher's views about gays by developing a freechoice project about male prostitution (Project Based Learning English Class). This project implies in itself a challenge to the socially constructed understanding of prostitution as both a female job to provide sexual services in exchange for money and a man's role as user of this sexual service. This chauvinistic construct of prostitution offers Andrés the opportunity to resist the ascriptions his teacher is constantly giving to gay individuals in general. Thus, Andrés assumes his gay identity because he feels, to some extent, harmed by those ascriptions, so he responds by linking masculinity (man) to prostitution, not as users, but as providers.

\section{The Gay Disease}

\section{The Pathologizing Discourse}

A homophobic discourse does not exist exclusively in the use of explicit insults, violent acts, bullying behaviors, or purposeful exclusion, yet this type of discourse is silent, unconscious, unnoticed, and normalized. In the next case, I will analyze a single vocabulary activity which has a great impact on the way Sergio reflectively positions himself and the way he is interactively, unconsciously positioned by one of his classmates. This occurs when a simple word, "AIDS", pops up in the activity. The teacher proposes an activity, a contest, to revise vocabulary about internal organs and diseases. He asks students to group themselves and to send a member of each group to view a piece of paper he holds in his desk; then, he asks them to go back to the group and describe, define, or exemplify the word until one of his/ her partners in the group says the word being described out loud.

35. ese día pues preciso toco SIDA

36. y esta (4) uhy.. (6) (pensativo)

37. después me dió más rabia a mi

38. porque yo no dije nada y la profesora; el profe perdón

39. lo que dijo fue uich no; no; no; no.

40. hizo como un comentario

yo no me acuerdo que fue lo que dijo y

41. yo quedé (4)

42. quedé así todo, como ja ver!

43. ya esa clase no me sentí bien

44. porque la vieja de nuestro grupo

45. lo único que se le ocurrió fue decir

46. la enfermedad que tienen todos los gays; i y yo! mmm

47. y todo el mundo dijo SIDA

(Sergio, personal communication 2010)

Sergio explains his own actions and his partners' actions by means of a plot, the event of the activity would not have been meaningful to him if it were not understood in the realm of his gay male gender construction and his understanding of the word AIDS; thus, he attributes to this event a special role and significance in relation to his life project, which will remain in his memory as part of a unique set that may construct his identity (mattering). 
The association of AIDS and gays is a fallacy and an idea to position LGBT individuals at a disadvantage with a negative presumption. The definition of the word AIDS as "the illness that all gay people suffer" provided by the student draws on a normalized homophobic discourse. One of Foucault's (1972) definitions of discourse is the one of "practices that systematically form the objects and subjects of which they speak" (p. 49). This is demonstrated in the limited stereotypical meaning assigned to the definition of the word AIDS provided by Sergio's classmate. Unintentionally, his classmate positions Sergio on the popular belief related to the presumption of AIDS as an exclusive gay disease; this assumption, needless to say, overcomes Sergio's individuality in his gender construction as a gay male and makes him question himself about the truthfulness and reliability of this presumption. He says:

50. pero como que a veces uno se pone a a (2) pensar

51. y dice: como que si es cierto

52. pues yo no conozco a ningún hetero

53. que tenga SIDA

y mis amigos del cuento si.

(Sergio, personal communication 2010)

In this case, Sergio appears to construct his own identity, rearticulating quickly an assembly of cultural signifiers attached to homosexual males. He understands that gay individuals are promiscuous and more likely to get HIV.

\section{Conclusions}

After briefly having analyzed these short range narratives, I have some evidence to respond to the questions of this study. The opportunities that an EFL class offers for gendered-narratives are evidenced in these accounts, for instance, the addressed classes aimed at revising grammar topics like superlatives, present perfect, simple past tense, or vocabulary exercises like parts of the body and diseases. As a matter of fact, those activities cannot, by any means, be detached from the existential features of the language. Even though these gendered-events may be unperceived by teachers and students, they do occur and they are born from what I call "common activities" that most of us as EFL teachers may, on a regular basis, carry on in our classes. In the new trends of EFL teaching as the CEF suggests and in the way curricula is designed, a great quantity of topics that deal with personal issues which are highly gendered are included. We as teachers must be aware of the fact that identities are hidden in our classrooms; thus, we have to be careful, assertive and tolerant promoters and users of inclusive language and activities.

In response to my second question, I have to declare that, indeed, gender seems to have a great effect on the EFL learning process of LGBT students. EFL Performance is also influenced by the learner's physical and emotional state: "an alert and relaxed learner is more likely to learn and to succeed than a tired and anxious one" ( CEF, 2002). LGBT students are constantly assessing and self-monitoring their words to avoid accidental disclosure of their identity; they are anxious and unrelaxed when they are asked questions about movies as in John's case, or singers as in Jorge's episode, or about AIDS, as in Sergio's short range narrative.

A high level of intrinsic motivation in regard to personal interests and individual needs is often perceived as relevant; for example, the use of activities that involve real life needs or the completion of meaningful tasks will be more likely to be developed in a more accurate way. Therefore, heteronormativity has an effect on learning since at least there is an obvious internal and external struggle to access to use EFL in certain situations and activities. Needless 
to say, this shadows the development of oral skills. Hence, I can suggest that in regards to self -image, when an LGBT student considers the classroom a hostile place to display his/her gender, she/he exhibits a higher level of inhibition and is less likely to take risks when participating in common activities that represent no challenge at all for heterosexual students. This, to a large extent, restrains and puts LGBT individuals at a disadvantage in regard to competences, strategies and skills development.

LGBT members are hidden and this fact is just unperceived by most of us as educators. The LGBT community in the EFL classroom is silent and passive, they have to face situations of marginalization and rejection. Moreover, these issues may have an impact on the way these students perceive and understand themselves in the world; they mingle and swap from one "world" to another being convinced of the fact that it is for their own good to be silent.

\section{Issues for Further Research}

Resistance has been the main concern to me since I started the preliminary stages of this study. In some venues, educators, directors, students, and even LGBT students do not see the value of this study for the sake of TEFL; some members of the academic field who hold a traditional view of the classroom do not find it appropriate or politically correct to address these topics. I claim that the same resistance turns into further proposals for research. There are still a lot of issues to be explored in order to unveil the reasons why these issues of sexual identities are surrounded by the shadow of taboo. Members of the academic community may turn themselves with these kind of questions among others: Why should LGBT issues be addressed in an EFL classroom? Are these issues relevant or pertinent? How could I cope with a situation of rejection or homophobia in the classroom? These questions are relevant and emerge from the lack of knowledge in the field.

\section{References}

Baxter, J. (2003). Positioning gender in discourse: A feminist methodology. Basinstoke: Palgrave McMillan.

Butler, J. (2001). Gender trouble: Feminism and the subversion of identity.

New York: Routledge publishing house.

Bruner, J. (2004). Acts of meaning. Cambridge: Harvard University Press.

Brockmeier, J. (2001) "Narrative identity and the reconstruction of the self." Narrative and identity. Amsterdam: John Banjamins publishing Company.

Cameron, D. (1997). Performing gender identity: Young men's talk and the construction of heterosexual masculinity. New York: Rutledge.

Castañeda-Peña, H. (2008). Interwoven and competing gendered discourses in a preschool EFL lesson, in Harrington, K. et al (eds.) Gender and Language.

Cox \& Gallois. (2006). Constructing constrast between self and others in talk - in- interaction. British Journal of Social Psychology, 39 (3) 381-398.

Derrida, J. (2001). Writing and difference. Chicago: University of Chicago Press Barcelona: Anthropos, 1989. (traducción al español)

Harré, R.(1990). The Self and others: Positioning individuals and groups in personal, political, and cultural contexts. Greenwood publishing group. California.

Fairclough, N. (1989). Language and power. New York: Longman

Fairclough, N. (1992). Discourse and social change. Cambridge, England: Polity Press.

Foucault, M. (1990). The history of sexuality (Vol. 1). New York: Random House.

Foucault, M. (1972). Modernism, post modernism and organizational analysis. New York: Random House

Guijarro, O.(2006). "Addressing queer \& GLBT issues in the EFL classroom". Cataluña: Universidad de Cataluña. 
Hall, S.(1997).Cultural identity and diaspora. In J. Rutherford (Ed.), Identity: Community, culture, difference (pp. 222-237). London: Lawrence \& Wishart

Heidegger, M. (1927). Being and time, (Trans, 1962), Oxford: Blackwell.

Linde, C. (1993) Life stories: The creation of coherence. Oxford: Oxford University Press.

Nelson,D.(2004). Sexual identities in English language education: classroom conversations in EFL. London: Routledge

Nicholson, L. (2001). Deconstructing queer theory or the under-theorization of the social and the ethical. In L. \& S. (Eds.)(pp. 116-141). Cambridge: Cambridge University Press.

Ricoeur, P. (1983). Time and narrative. Chicago, IL: Chicago University Press.
Spurlin W. (2000). Lesbian and gay studies and the teaching of English positions, pedagogies, and cultural politics. Urbana, Illinois, NCTE.

Summerhawk, B. (2001). Personal stories of Japanese lesbians, gays, bisexuals and transsexuals. Orwich, VT: New Victoria.

Sunderland, J (2002). Exploring gender: questions and implications for English language education. London: Cambridge University Press.

Walkerdine, V. (1990). Boys' underachievement: social class and changing masculinities. London: Falmer Press.

Wooffitt, R. (2005). Conversation analysis and discourse analysis. London: Sage.

THE AUTHOR

FRANCISCO RONDÓN CÁRDENAS holds a masters degree in Applied Linguistics from Universidad Distrital Francisco José de Caldas. He is an Academic Supervisor for the Saturday Program at Centro Colombo Americano, He carries out research in the identity field of applied to TEFL and some small scale projects with teacher observation as part of his job as a supervisor. 